\title{
Between hospitality and asylum: A historical perspective on displaced agency
}

\section{Elena Isayev*}

Elena Isayev is a Professor of Ancient History and Place at the University of Exeter. She also works with Campus in Camps in Palestine, and is a Trustee of Refugee Support Devon.

\begin{abstract}
This article aims at positioning the agency of the displaced within the longue durée, as it is exposed in contexts of hospitality and asylum, by articulating its key modes: contingent, willed and compelled. Using the ancient world as its starting point, the article exposes the duplicity in conceiving of the current condition of displacement as transient or exceptional. As such, it argues for the urgent need of a shift in the perception of displaced persons from that of impotent victims to potent agents, and to engage with the new forms of exceptional politics which their circumstances engender.
\end{abstract}

Keywords: migration, refugee camp, agency, ancient history, suppliants, asylum-seekers, refugee, state of exception, hospitality, guest-friendship, sanctuary, xenia, reciprocity, Zeus Hikesios, Agamben, Arendt, Derrida, Homer, Euripides, Aeschylus, Isocrates.

* For insight into the real meaning of refugee agency, and opportunities for thinking together, I thank my friends and colleagues at DAAR, Campus in Camps, and Dheisheh Refugee Camp in the West Bank in Palestine, especially Isshaq Al'Barbary, Sandi Hilal, Athar Mufreh, Alessandro Petti and Diego Segatto. I am also indebted to the many scholars, some as young as 7, at the Calais refugee camp in France for their unconditional hospitality. For the possibility of sharing and developing these ideas, I am grateful to Andrew Thompson and the many participants of the dynamic conference on "Refuge and Refugees in the Ancient World" held at the University of Columbia in 2016. This article would be much the poorer without the insightful suggestions of the editors and reviewers. 


\section{Introduction}

The capacity for action - agency - of forcibly displaced persons needs urgent attention. ${ }^{1}$ To not understand its potency and discount it is to forsake over 100 million people to a false state of victimhood, and to ignore the emergence of new forms of collective action and "governance". Responses to conditions of displacement, or de-placement, refute the classification of such contexts as "states of exception" - defined by the impossibility of politics and agency. For Agamben, the "camp" is where the temporary "state of exception" is given spatial permanence. ${ }^{2}$ Yet despite systems of constraint and suspension of rights, such conditions as experienced in the intransient refugee camps can still generate an exceptional politics that is innovatively flexible and adaptable. It is a politics that has equal potential for influence through progressive methods as through intimidation. Without romanticizing, there are lessons to be learned from this situation, which defies the liminality of displaced existence. The aim of this paper is to position the agency of people who are displaced within the longue durée, as it is exposed in contexts of hospitality and asylum, by articulating its key modes: contingent, willed and compelled.

Exceptional are the policies and the negotiations that accompany the political and moral dilemmas of how to address the stranger at the threshold. What happens across that threshold has, once again, become central to the understanding of what it means to inhabit the earth as a community. Some 3,000 years ago, the measure of society was encapsulated in what happened at the moment of reaching across that liminal space-inhospitable treatment of a stranger was used to make a more general statement about the negative character of the community as a whole. Seminal to the narratives of the most well-known surviving works of ancient literature are the encounters between the guest and the host; between those who seek asylum and those who are asked to provide it. There is a timelessness to these encounters in ancient writings that, like the intransient permanence of today's camp, challenges the liminality of displaced existence.

Following a preliminary reflection on ancient terminology and contemporary approaches, this article begins by critically presenting some of the features of ancient hospitality, asylum and supplication, while introducing the main cases that will act as witness. It then proceeds with a diagnosis of the three modes of displaced agency. From the ancient context, it first draws on the

1 Forcible displacement includes that which is the result of conflict, poverty, climate change or sociopolitical circumstances that make life unendurable, and there is no distinction made between persons who have been displaced across national borders and those displaced within their own States.

2 For the state of exception, which refers to an emergency response by sovereign States leading to suspension of the juridical order, see Giorgio Agamben, State of Exception, University of Chicago Press, Chicago, IL, 2005; Jef Huysmans, "The Jargon of Exception - On Schmitt, Agamben and the Absence of Political Society", International Political Sociology, Vol. 2, 2008; Carl Schmitt, The Concept of the Political, trans. George Schwab, University of Chicago Press, Chicago, IL, 1996 (first published 1932); Carl Schmitt, Political Theology: Four Chapters on the Concept of Sovereignty, trans. George Schwab, University of Chicago Press, Chicago, IL, 2005 (first published 1922). 
Homeric epic and then focuses on the evidence for asylum requests and their function in Greek tragedies, written for the audience of the Classical polis (fifthcentury BCE city-State). It also considers later historical episodes, such as Isocrates' record of the Plataean plea for refuge to the Athenians in the fourth century, the Polybian account of "camp" politics during the Carthaginian Mercenary War of the third century BCE, the Roman Republican dispute on foreigners' rights to the city in Cicero's writings, and briefly the encounters with people seeking refuge in the works of Caesar and Virgil. These will be used to investigate the bases on which asylum is sought and decisions are made, including threat and peer pressure, religious and moral obligations, legal duty, reputation, reciprocity, kinship, and utility - the potential for service. Within these negotiations, the site where they take place is also relevant, whether a private, public or other liminal space, such as a sanctuary. The stage on which the discourse is played out defines the roles of the actors and intermediaries involved, including those of the leaders (displaced or not), the community and the divine. On it is exposed the potential for agency and the struggle of fulfilling, often conflicting, obligations to one's fellow community members and to outsiders. In the second half of the article these historical cases will be brought to bear on exploring the different modes of agency, and the article will consider the works of contemporary thinkers as well as recent illuminating examples such as the Dheisheh Refugee Camp in Palestine.

\section{Past and present understandings}

Increasingly, investigations into ancient mobility challenge prevailing conceptions of a natural tie to the land and a demographically settled world, showing that much human mobility was ongoing and cyclical. ${ }^{3}$ The generic term for migrant, for example, is not easily discernible in Ancient Greek, nor in Latin usage until it gains currency in the fourth century CE, well into the Roman Imperial period. ${ }^{4}$ There was no interest in categorizing all those on the move under one label. The closest equivalent to "migrant" is transitor (literally, one who goes over or is a passer-by), which only appears in Late Antiquity (c. 300-700 CE). In this later

3 See the following, with earlier references: Peregrine Horden and Nicholas Purcell, The Corrupting Sea: A Study of Mediterranean History, Cambridge University Press, Cambridge, 2000; Elena Isayev, Migration, Mobility and Place in Ancient Italy, Cambridge University Press, Cambridge, 2017; Laurens E. Tacoma, Moving Romans: Migration to Rome in the Principate, Oxford University Press, Oxford, 2016.

4 Terms do exist for the foreigner/outsider in Ancient Greek - xenos (although initially the term could also be used to mean host), or enemy - polemios; and in Latin, for the friendly outsider, hospes, and the one who is much less so, an enemy, hostis (originally the term was also used to mean stranger or foreigner). None of these express the same sentiment as the modern usage of "migrant". Instead, they focus on the specific relationship of the individual to the host community: see Cicero, De Officiis, 1.12.37; and Varro, Lingua Latina, 5.3, with discussion in E. Isayev, above note 3, Ch. 2.

5 Ammianus 15.2.4: Charlton T. Lewis and Charles Short, A Latin Dictionary, Oxford University Press, Oxford, 1900. 
period, concepts of immobility became part of the repertoire of virtue. ${ }^{6}$ The emergence of new terminology, such as transitor, is an indicator of shifting attitudes to mobility and the status of individuals, and an expression of changing methods of control. It exposes how fleeting are the conventions that take shape here and now by highlighting moments of change in conceptualizing mobility and the definition of those on the move.

The actions and decisions within host-guest encounters determined (and perhaps still determine) the positioning of a society on the spectrum of just, civilized or barbarian. For Derrida, whose thought experiments draw on ancient writings, hospitality is the essence of culture. ${ }^{7}$ Homer's world of the Odyssey is wholly constructed through its protagonist's experience as a guest and suppliant among the inhabitants dwelling on the real and imagined shores of the Mediterranean. As Odysseus is coaxed to tell the story of his adventures, what his hosts are most keen to know is whether those he met were kind or hostile to strangers. The barbarism of Polyphemos, the one-eyed cyclops, is revealed through his subversion of the duties owed to guests - not least eating, rather than feeding, them. ${ }^{8}$ Athena, the grey-eyed goddess, disguises herself as a guest at the house of the absent Odysseus to get the measure of his son Telemachus. ${ }^{9}$ The most supreme ancient gods, including Zeus himself (in the guise of Xenios, as protector of guests, and Hikesios, as protector of suppliants), mete out harsh punishment on those who transgress the rules of hospitality.

Beyond Homer's world of elite warrior-heroes, for the dramatists of the nascent democracies of Classical Greece, the treatment of the stranger continued to be pivotal in capturing the most polemical issues of their times. This is most explicitly portrayed in such plays as Aeschylus' Suppliant Women and Euripides' Children of Herakles, which will be considered in more detail below. The hostguest or suppliant encounters are played out to expose the tensions of morality, responsibility and obligation that lie between State and individual, questioning the balance of power and the true place of decision-making. They also zero in on the conflict between agency and victimhood.

Perhaps here the necessary momentum can be found to shift the perception of displaced persons as impotent victims to that of potent agents, who are equally invested in addressing shared global challenges. In the twenty-first century, those involved in more progressive humanitarian endeavours recognize this acutely. Activists in such organizations as the City of Sanctuary Movement show distress at having to present people seeking sanctuary as helpless victims to the public,

6 P. Horden and N. Purcell, above note 3, p. 384; Bruno Pottier, "Contrôle et mobilisation des vagabonds et des mendiants dans l'Empire romain au IVe et au début du Ve siècle”, in Carla Moatti, Wolfgang Kaiser and Cristophe Pébarthe (eds), Monde de l'itinérance en Méditerranée de l'antiquité à l'époque moderne: Procédures de contrôle et d'identification: Tables rondes, Madrid 2004-Istanbul 2005, Bordeaux, 2009.

7 Jacques Derrida, Of Hospitality: Anne Dufourmantelle Invites Jacques Derrida to Respond, trans. Rachel Bowlby, Stanford University Press, Stanford, CA, 2000.

8 Homer, Odyssey, Book 9.

$9 \quad$ Ibid., Book 1. 
the media and government authorities, in order to get a sympathetic response. ${ }^{10} \mathrm{~A}$ related challenge for such movements is the illusion of equality: how to deal with the reality of exclusion in terms of rights, politics and protection for those who are waiting to have their asylum claims heard, while at the same time fostering an environment that encourages engagement, on equal terms, between citizens and asylum-seekers, refugees and undocumented immigrants. These challenges embody the perplexities of human rights confronted by Arendt, which, while promising equality irrespective of citizenship status, are still articulated within the framework of the nation-State. ${ }^{11}$ Nationality remains the basis of entitlement to rights, despite the guarantees offered for legal personhood to those deemed stateless by international human rights law. ${ }^{12}$ Gundogdu's reinterpretation of Arendt's analysis of statelessness and human rights articulates these concerns by pointing to the depoliticizing trends that have emerged with the convergence of human rights and humanitarianism, with an increasing emphasis on suffering bodies. ${ }^{13}$ Such a focus undermines the ability of displaced persons to make their actions and their speech relevant, hence excluding them from political community, which for Arendt equates to expulsion from humanity.

Scrutinizing claims of inclusivity, Rancière's work tracks the potential for action and power among people whom society positions on its margins. Fundamental to his idea of "equality of intelligences" are workers" practices in nineteenth-century France. This "proletariat", despite the constrictions of the rigorous regime, through their writings, poetry and magazines - their discourse subverts "the order of time prescribed by domination, ... asserting against the rationality imposed by its managers, their governments and experts, a capacity for thought and action that is common to all". ${ }^{14}$ For Arendt, early labour movements were also a way to explore the refusal of passive victimhood in The Human Condition, showing how workers through their actions engendered a new politics in the wider community. Scholarship dedicated to capturing and confronting the current "migration crisis" signals the urgent need to recognize the agency of displaced people, ${ }^{15}$ and their potential to generate new active forms

10 Jennifer J. Bagelman, Sanctuary City: A Suspended State, Palgrave Macmillan, New York, 2016, pp. xviii, 18.

11 Hannah Arendt, The Origins of Totalitarianism, Harcourt, New York, 1968. Addressing these issues directly is the work of Ayten Gundogdu, Rightlessness in an Age of Rights, Oxford University Press, Oxford, 2015.

12 See International Covenant on Civil and Political Rights, UNTS Vol. 999, 16 December 1966 (entered into force 23 March 1976), Art. 2(1); Universal Declaration of Human Rights, 217 A (III), 10 December 1948, Art. 14.

13 A. Gundogdu, above note 11, pp. 16, 76, 116.

14 Jacques Rancière, Proletarian Nights: The Workers' Dream in Nineteenth-Century France, trans. John Drury, Verso Books, New York, 2012, pp. xi-xii.

15 Some enlightening studies include J. Bagelman, above note 10; Gideon Baker, Politicising Ethics in International Relations: Cosmopolitanism as Hospitality, Routledge, London, 2011; Seyla Benhabib, The Rights of Others: Aliens, Residents, and Citizens, Cambridge University Press, Cambridge, 2004; Megan Bradley, "Rethinking Refugeehood: Statelessness, Repatriation, and Refugee Agency", Review of International Studies, Vol. 40, No. 1, 2014; Joseph H. Carens, The Ethics of Immigration, Oxford University Press, New York, 2013; Matthew J. Gibney, The Ethics and Politics of Asylum: Liberal Democracy and the Response to Refugees, Cambridge University Press, Cambridge, 2004; Marta Kuzma, Pablo Lafuente and Peter Osborne (eds), The State of Things, Office for Contemporary Art Norway, Oslo, 2012; Martha C. Nussbaum, "Kant and Stoic Cosmopolitanism", Journal of Political Philosophy, Vol. 5, No. 1, 1997. 
of engagement with State-based actors, their governments, and supra-national agencies, not least the United Nations (UN).

To make such agency explicit is to acknowledge that its potential power is what induces fear within host communities: the perception of a "menacing mass of humanity that huddles just beyond the frontiers of nationhood". ${ }^{16}$ Addressing this fear directly, through a bodily performance of vulnerability, ancient supplication rituals helped to sanction the suppliant as a figure of pity rather than threat. Such acts, however, were conducted with full awareness of the paradox embodied within them, as the evidence below will show. The performance of vulnerability, the possibility of threat beneath it, and the diverse modes of agency that have the potential to induce change, destabilize or bring harm are not distinctive attributes of contexts of displacement - they are equally prevalent among all communities. It is beyond the scope of this paper to fully address why it is that civilian outsiders are perceived as potentially more dangerous than fellow community members, but one need only think of the numerous civil wars that are at the root of displacement, not least today.

Despite attempts at classification by bloodline and citizenship, these contexts showcase the constructed nature of kin and outsider. This flexibility allows for kin to become estranged and for strangers to lose their foreignness. The Athenian figure of the metic (metoikos) - a resident alien with privileges but without citizenship - provides a site of discourse for these issues in Euripides' tragedy Ion, and in Plato's Republic, which is set in a metic's home. Within these works there is less attention on citizenship as legal standing than on the associated cultural milieu of living as a citizen or a non-citizen. ${ }^{17}$ Ancient narratives show a deep interest in the process of such transformations, the articulation of belonging and the porosity of citizenship categories.

\section{Tensions within ancient hospitality and asylum}

For Derrida, Homeric epics provide a laboratory in which to test the extremes of hospitality, as if probing its desirability. ${ }^{18}$ In diagnosing the uses and abuses of hospitality, Derrida questions the very nature of its existence in light of the impossibility of it being unconditional. Some argue that xenia - the ancient Greek term for hospitality, or more specifically guest-friendship - is by its nature a reciprocal relationship. Once the question is asked of the outsiders as to who they are, the encounter becomes governed by some form of reciprocity and the

16 For De Genova reflecting on Anderson's conception of nationhood, see Nicholas De Genova, "The Deportation Regime: Sovereignty, Space, and the Freedom of Movement", in Nicholas De Genova and Nathalie Peutz (eds), The Deportation Regime: Sovereignty, Space, and the Freedom of Movement, Duke University Press, Durham, NC, 2010, p. 49; Benedict Anderson, Imagined Communities: Reflections on the Origin and Spread of Nationalism, Verso Books, London, 1991.

17 Demetra Kasimis, Classical Greek Theory and the Politics of Immigration, Cambridge University Press, Cambridge, forthcoming; Demetra Kasimis, "The Tragedy of Blood-Based Membership: Secrecy and the Politics of Immigration in Euripides's Ion”, Political Theory, Vol. 41, No. 2, 2013.

18 J. Derrida, above note 7, p. 22. 
hospitality is no longer hyperbolic or unconditional, which Derrida presents as the "violence of the question". ${ }^{19}$ One of the earliest examples of outwardly unconditional hospitality that appears in Western literature is the legendary reception of Odysseus in the house of Arete and Alkinoos, the king and queen of Scheria. ${ }^{20}$ It provides a contrast to less successful encounters with more reluctant or violent hosts, such as with Polyphemos in his cave, an episode where the guests too are found wanting, exposing the precariousness of these confrontations. On Scheria, however, Odysseus gets a different welcome. Even as a shipwrecked, desperate and semi-naked war hero, he manages to find his way into the palace with the help of the gods. A helpless victim, he clasps the knees of Arete in supplication, having nothing to offer but his bare life. Without even being asked his name or origin, or his circumstances, he is bathed, fed and given shelter - an exemplary enactment of the duties of xenia, which could also include assistance with returning home or access to the hosts' support network. Only later is Odysseus finally enticed to divulge his story, through which the epic unfolds. His hosts, now recognizing him as one of the Trojan War heroes, offer him a ship and provisions to convey him home to Ithaca. The line between suppliant and guest is not clear-cut in this episode, which encapsulates the transformation from one to the other. It is questionable to what extent this ideal reception is meant to act as a model, implying that both guest and suppliant should receive equal treatment. After all, we, the all-seeing listeners and readers of the story, know Odysseus' true identity all along - a member of the privileged elite who has the capacity to reciprocate or provide equal service. Rather, what is of interest in this episode is that by moving from suppliant to guest, Odysseus' true agency is revealed. It is evident through the recognition of his role as a victorious, powerful warrior with his own story. His actions are interconnected with, and affect, the lives of the other protagonists, not least his hosts. In the wider narrative, it is his decisions that drive the plot. This embodied duality of victim and agent appears again and again through ancient literature, and it will be drawn on here especially from contexts that are more explicitly those of asylum.

In Homer's epic Odyssey, which is set in the face-to-face society of elite warriors that existed prior to the emergence of the polis, the scenario is of an individual who requests asylum and hospitality at the threshold of the head of the household - who alone can make the decision as to whether to grant xenia. Several hundred years later, once we move towards the world of city-States with democratic institutions, the responsibilities and obligations become less clear, and at times the people (demos) end up in opposition to their leaders. Further complications arise when those seeking refuge arrive in groups and make their appeals not at domestic thresholds but at other liminal places, such as altars and sanctuaries. The waiting state of the asylum-seekers at these ancient sites has commonalities with the state of suspension that we find in refugee camps and detention centres today, although with a number of important differences, not 
least the much shorter periods of time spent there. The ancient sanctuaries are often positioned on the edges of settlements or at some distance from them. In part, this may be a precaution against any threat that suppliants may pose, but also for better accessibility to these sacred sites in their primary capacity as hosts to worshippers and festival-goers during religious celebrations. ${ }^{21}$ Accommodating asylum-seekers within these precincts was so common that their presence was likened to that of nesting birds, and there is some evidence that provision for additional lodgings were necessary. ${ }^{22}$ Since the position of sanctuaries is separate from the everyday spaces of the community, appeals and negotiations for protection, acceptance or support are by necessity made through representatives and intermediaries. This means that direct appeals - which rely on pathos (pity), as those of Odysseus through his body, his gestures and his touch - become impossible, distancing the suppliant from the potential host and making any transformation to guest more difficult. Furthermore, the position of host becomes more ambiguous as it is no longer the individual but the community which is appealed to, hence diffusing the responsibility to provide hospitality.

These tensions - visible in the ambiguous figure of the host, whether community or individual, and in the juxtaposition of helplessness and power of the suppliant - are addressed explicitly in Aeschylus' Greek tragedy The Suppliant Women. The play, which is the remaining part of a trilogy that did not survive, was performed in the 460s BCE, but is set in the mythical past of the Bronze Age (c. 3000-1000 BCE). It tells the story of fifty Danaids, the daughters of Danaeus (the brother of a mythical Egyptian king), who have fled Egypt with their father to find refuge in the land of the Argives. They flee to escape forced marriage to their suitor cousins, who are in pursuit. As the play opens we find the women on the shores of a liminal space between the sea and the city, clinging to the altars of a sanctuary. From here they supplicate the king Pelasgos to give them protection: asylum in his city of Argos is what they want. The king's response is as follows: ${ }^{23}$

You are not sitting at the hearth of my house.

If the city as a whole is threatened with pollution,

it must be the concern of the people as a whole to work out a cure.

These seemingly helpless maidens respond with surprising force:

You are the city, I tell you, you are the people!

A head of state, not subject to judgement, you control the altar, the hearth of the city

21 Thucydides 3.75.5-81.3, on wanting to keep suppliants at a distance and out of town, in case of uprising and threat.

22 Herodotus 1.159.3; Ulrich Sinn, "Greek Sanctuaries as Places of Refuge", in Nanno Marinatos and Robin Hagg (eds), Greek Sanctuaries: New Approaches, Routledge, London, 1993; Angelos Chaniotis, "Conflicting Authorities: Asylia between Secular and Divine Law in the Classical and Hellenistic Poleis", Kernos, Vol. 9, 1996, p. 69.

23 Aeschylus, The Suppliant Women, trans. Alan H. Sommerstein, Loeb Classical Library, 2009, lines 365375 . 
In their plea, the Danaids refuse to accept their predicament, that by taking sanctuary at public shrines they have made themselves suppliants not of an individual, the king Pelasgos, but of the Argive State.

Some readings of Aeschylus' tragedy, in attempting to explain the forceful authoritative voice of the suppliant women, position them alongside outdated aristocratic networks: the old oligarchic regime and the threat of tyranny. ${ }^{24}$ The hosts, Pelasgos and the Argives, on the other hand, are meant to represent Athens' nascent democracy. Furthermore, the suppliants' incomprehension of a political system in which the people have the final decision-making power has been attributed to their ambivalent otherness. ${ }^{25}$ Yet it is they, in the end, who hold the ultimate power, and they succeed in their pleas. The historical context of the play's creation for a mid-fifth-century BCE Athenian audience is important. In this period we can perceive an ideological move away from the Archaic oligarchic mindset of supra-State elite networks, towards a more exclusive, if imperialistic, Classical democracy of Periclean Athens (from $461 \mathrm{BCE}$ ). It was a new setting that did not tolerate internal class divisions. With this change one can witness a shift from the private ties of hospitality to the more public ones of asylum, which now required a proxenos - a sponsor or intermediary. ${ }^{26}$ The new location of appeals from the distance of public shrines created different conditions to those of the family hearth and the knees of Arete, in front of which Odysseus performed his supplication ritual.

The historical context alone is not enough to explain the authoritative voice of Aeschylus' Danaids, nor those of numerous other suppliants whose tales have come down to us from the ancient world, whether mythical or not. These stories reveal the agency which suppliants and refugees possess and enact, and not through direct voice alone, but also through their being and their existence as part of a group of displaced people. Its potency remains even when it is veiled by the rituals of supplication that brand the body with the symbol of vulnerability. ${ }^{27}$ The paradox of the asylum-seeker's position is acknowledged by Aeschylus in his tragedy, when the father of the Danaids counsels on how his daughters should present themselves to the Argives: ${ }^{28}$

24 Geoffrey, W. Bakewell, Aeschylus's Suppliant Women: The Tragedy of Immigration, University of Wisconsin Press, Madison, WI, and London, 2013, pp. 13, 30-32; Susan G. Cole, Landscapes, Gender, and Ritual Space: The Ancient Greek Experience, University of California Press, Berkeley, CA, 2004, p. 63; Froma Zeitlin, "The Politics of Eros in the Danaid Trilogy of Aeschylus", in Ralph Hexter and Daniel Seldon (eds), Innovations of Antiquity, Routledge, London and New York, 1992.

25 Lynette G. Mitchell, "Greeks, Barbarians and Aeschylus' 'Suppliants”, Greece \& Rome, Vol. 53, No 2, 2006, p. 214.

26 G. W. Bakewell, above note 24, pp. 30-31; Robert Garland, Wandering Greeks: The Ancient Greek Diaspora from the Age of Homer to the Death of Alexander the Great, Princeton University Press, Princeton, NJ, and Oxford, 2014, p. 13; Michael B. Walbank, Athenian Proxenies of the Fifth Century B.C., Samuel Stevens, Toronto, 1978, pp. 2-3.

27 J. J. Bagelman, above note 10, p. 6; John Gould, "Hiketeia", Journal of Hellenic Studies, Vol. 93, 1973; Fred S. Naiden, Ancient Supplication, Oxford University Press, Oxford, 2006.

28 Aeschylus, above note 23, lines 191-199. 
$[\mathrm{H}]$ old reverently in your left hands your white-wreathed suppliant- branches, sacred emblems of Zeus the enforcer of respect,

and answer the natives in words that display respect, sorrow and need,

as it is proper for outsiders to do,

explaining clearly this flight of yours which is not due to bloodshed.

Let your speech, in the first place, not be accompanied by arrogance,

and let it emerge from your disciplined faces and your calm eyes

that you are free of wantonness.

Recognizing the inconsistency of their predicament, he goes on to stress:

Remember to be yielding - you are a needy foreign refugee:

bold speech does not suit those in a weak position.

The ritual of supplication might give the appearance of a helpless, pitiful victim, but beneath it remains the asylum-seeker with a strong voice.

A similar exposition of the continuum that exists between victimhood and power is evident in the more historic case of the failed plea by the Plataeans to the Athenians, which is recounted in Isocrates' 14th speech Plataicus. The events he reports took place in the Hellenistic period, some 100 years after Aeschylus' play was performed. The Plataean predicament was the result of the Theban takeover of their home in the 370s BCE, forcing the city's population to seek refuge and assistance from Athens. In their appeals, which were made by an orator to the Athenian assembly in $373 \mathrm{BCE}$, they seem to shift between three different modes. At first they appear as weak, destitute and helpless, at the mercy of their potential hosts. ${ }^{29}$ At the same time, however, they manage to present themselves on a more equal footing with the Athenians, by pointing to their shared experience of exile, which Athens too had suffered in its own former wars. ${ }^{30}$ They go further, by warning that the Athenian response to their plea will affect the balance of international diplomatic relations and alliances. In other words, if Athens does not heed their request, it will lose its allies to Sparta. ${ }^{31}$ Suppliants could exert further pressure by pointing to how the hosts' actions would be judged globally among their peers, whether through praise or loss of honour. Surely Athens would not want to lose her ancestral reputation of being kind to strangers, by ignoring the requests of the Plataeans? The image of asylum-seekers from the ancient world is one not of passive, waiting victims, but of actors who keep the pressure on to have their claims addressed. This holds true even if in more cases than not they are unsuccessful and the rejection of their requests leads to expulsion, enslavement or death. 


\section{Positive reasons for requesting asylum}

Collective appeals for asylum in the ancient world were usually made on the basis of two positive criteria: kinship and service. These tended to be preceded by assertions of the just cause for seeking refuge. ${ }^{32}$ Such clarification was necessary because protection, especially at sanctuaries, was also sought by those fleeing from retribution for criminal acts, including murder. Aeschylus' suppliant women, for example, make it clear that they are not requesting asylum due to any fault of their own. One of the strongest arguments for their request, which explains why they have chosen to seek refuge in Argos, is based on the claim that their mythical ancestors came from this land, meaning that they are the distant kin of the Argives. Kinship provides the foundation for one of the most robust claims that can be made, implying an ancestral right to hospitality. The suppliant Egyptian Danaids of Aeschylus' tragedy recount how they are the descendants of Io, a priestess of Hera from Argos whom Zeus took as his lover before she was turned into a heifer that wandered the world, eventually ending up in Egypt, where she was given human form again. Such mythical claims are part of the diplomatic toolkit which we find used throughout the centuries, even in historical contexts. At the time of the Roman Republic, for example, the people of Ilium - a city believed to be the site of ancient Troy - tried to obtain Rome's favour by playing on the idea that they were Trojan kin, and their city ultimately that of the Roman ancestors. ${ }^{33}$ Rome found this to be dubious grounds for giving in to their requests. The historian Polybius is scathing about such mythical kinship claims, and exposes their fabrication and proliferation for political ends. ${ }^{34}$

More difficult to discount are historical claims of kinship, such as those of the Plataeans in their pleading for Athenian protection: ${ }^{35}$

For indeed we are not aliens to you; on the contrary, all of us are akin to you in our loyalty and most of us in blood also; for by the right of intermarriage granted to us we are born of mothers who were of your city. You cannot, therefore, be indifferent to the pleas we have come to make.

In their appeal, the Plataeans remind the Athenians of their joint family ties through intermarriage. ${ }^{36}$ These date back to the previous century, when Athens had taken in Plataean refugees who had escaped the takeover of their city by Thebes in 428-27

32 A. Chaniotis, above note 22, pp. 84-85.

33 Polybius 22.5. For examples of communities using Roman links with Troy to their own advantage, see Filippo Battistoni, "Rome, Kinship and Diplomacy", in Claude Eilers (ed.), Diplomats and Diplomacy in the Roman World, Brill, Leiden and Boston, MA, 2009; Richard Gordon and Jane Reynolds, "Roman Inscriptions 1995-2000", Journal of Roman Studies, Vol. 93, 2003, pp. 222-223. The inscription from Lampsakos demonstrates the way that an embassy to Rome used its connection to Ilium, and kinship in diplomatic negotiations: see Roger S. Bagnall and Peter S. Derow (eds), Historical Sources in Translation: The Hellenistic Period, 2nd ed., Blackwell, John Wiley \& Sons, Oxford, 2004, No. 35.

34 Polybius 22.5.

35 Isocrates 14, Plataicus, trans. George Norlin, Loeb Classical Library, 1980, lines 51-52.

36 Isocrates 14, Plataicus, line 51. 
BCE. ${ }^{37}$ They claimed that as there had been intermarriage, many of those from Plataea were actually descendants of the Athenians. It is worth noting that the Plataeans make no recourse to Zeus as the protector of guests and suppliants in their historic plea to the Athenians. The most effective pleas are those which succeed in reducing the gap between the host and guest or suppliant, by bringing the seemingly unknown into the realm of the familiar. Through the revelation of pre-existing ties or the potential of future ones, the suppliant is able to shift from being an outsider to a position within the inner circle of the host, to whom obligations are owed.

The other criteria for claiming asylum is based on past and/or potential future services provided by those seeking refuge. The Plataeans, drawing on their former alliances and loyalty to the Athenians, indicate that they would continue to support the Athenians in any forthcoming ventures. It was they, after all, who had fought alongside Athens against the Persians at Marathon in the fifth century BCE. ${ }^{38}$ This element of service, especially the potential of future service, appears increasingly important. In the context of Roman mythology, Virgil's epic Aeneid, written at the end of the first century BCE, recounts the journey of the Trojan refugee-hero Aeneas and his followers, as they seek a new home after the destruction of their city of Troy. Eventually, with divine insistence, they arrive in Italy and put themselves in the service of king Latinus, who allows them to settle on nearby land once they help him overcome his enemies. The utility offered by the suppliants, therefore, acts almost as a compensation for their inability to provide reciprocal duties of xenia. ${ }^{39}$ This is some way from the idealized unconditional xenia of the Homeric world, and we may question whether the institution of guest-friendship remains applicable when hospitality and asylum are granted on the basis of utility. The ultimate "violence of the question", the antithesis of Derrida's hyperbolic hospitality, is that it can reduce human life to its bare utility. The destitute, war-ravaged Gallic Alesians, who made it to Caesar's Roman camp, pleaded to be given refuge. They even offered themselves up as slaves in exchange for food, only to have Caesar tell his troops to set up guards at the gate, preventing their entry. We know about this episode from Caesar's own account of it in his Gallic Wars. ${ }^{40}$ The banality of its description, lacking any fear of retribution from the gods or the judgement of peers, reads as an act against humanity. The Alesians did not even have enough utility to be enslaved. ${ }^{41}$

37 Thucydides $2.2 ; 2.71 ; 3.20 .2$.

38 Isocrates 14, Plataicus, lines 45-47, 57; Isocrates, Panathenaicus, line 93; Herodotus 6.108-111.

39 Elizabeth Belfiore, "Harming Friends: Problematic Reciprocity in Greek Tragedy", in Christopher Gill, Norman Postlethwaite and Richard Seaford (eds), Reciprocity in Ancient Greece, Clarendon Press, Oxford, 1998, p. 144.

40 Caesar, Bellum Gallicum, 7.78.

41 On utility of foreigners in the ancient context, see Josiah Ober, "The Instrumental Value of Others and Institutional Change: An Athenian Case Study", in Ralph M. Rosen and Ineke Sluiter (eds), Valuing Others in Classical Antiquity, Brill, Leiden and Boston, MA, 2010. On a similar note, Arendt explores with raw clarity the notions of utility during the Nazi regime, confronting the murder of millions who too were deemed not to have enough utility even to be enslaved: H. Arendt, above note 11. 
These brief forays into ancient responses to appeals for refuge and hospitality only touch the surface of the subject, leaving many vital questions unanswered. ${ }^{42}$ To what extent, for example, is utility a constant factor through history when making decisions about reaching out to strangers across the threshold, even when it is couched in the duties of xenia? ${ }^{43}$ What is the difference in treatment between elite and non-elite groups? ${ }^{44}$ In what way does the context of the events influence the response: are some deemed more or less deserving, even if their predicament is the same? ${ }^{45}$ How significant for the host's decision is the length of time that the guest or suppliant might stay, or the likelihood of a return to their home? (This issue does not seem to be of interest at the point of appeal.) How does the "international" standing of the host community influence their potential to take in asylum-seekers? Is it the case that the more powerful and wealthy the community, the more resistant it is to asylum claims, with better-developed mechanisms to avoid them in the first place? ${ }^{26}$

All these questions - and one could think of many more - are equally relevant today, as evidenced by the numerous studies that take on the challenges they bring. ${ }^{47}$ Fundamentally, what they address is the gap or the tension between the ethical argument for responding to the needs of those who request hospitality or asylum, and the factors on the ground that affect the ultimate decision to welcome or to turn away people who are displaced. At the core of this tension and the discourse itself are the people about whom the decision is being made, although often they appear silent. Even these questions, which are mainly posed from the perspective of communities organized into States, seem to deny them the possibility for action, as their displacement positions them outside of the system. The aim here is to identify the potential for agency under such conditions. Furthermore, it is to show the interdependence between those who consider themselves on the inside and those on the outside of State-based structures.

\section{Three modes of displaced agency}

What follows is a propositional model for displaced agency based on three modes: contingent, willed and compelled. In exploring the robustness of this framework, the aim is to expose the way these diverse forms of agency are generated under conditions of displacement, even if they are not unique to it. It is not the intention to provide a comparative study of how these modes play out in ancient and modern times. Rather, through an expansive view from a different

42 Many of the themes in the following questions will be addressed in the forthcoming special issue of Humanities on "Displacement and the Humanities: Manifestos from the Ancient to the Present", edited by Elena Isayev and Evan Jewell.

43 R. M. Rosen and I. Sluiter, above note 41.

44 C. Gill, N. Postlethwaite and R. Seaford, above note 39.

45 D. Kasimis, above note 17.

46 For the twenty-first-century context, this issue is controversially addressed in J. H. Carens, above note 15.

47 G. Baker, above note 15; S. Benhabib, above note 15; M. Bradley, above note 15; M. J. Gibney, above note 15; M. Kuzma, P. Lafuente and P. Osborne, above note 15. 
somewhere and somewhen, it is to allow for the emergence of patterns and perspectives that may be difficult to recognize at close quarters.

\section{Contingent}

At its most basic, "contingent" refers to that mode of agency which is unforeseen, with latent qualities that are conditionally activated - in this context - at the moment of displacement. Displaced persons, in the resulting juxtaposition with those who are "placed", provide the privileged view of the outsider which affects "insider" communities' self-definition and articulation of boundaries. ${ }^{48}$ They also hold the power to influence how such communities are perceived globally, as the treatment of people seeking refuge becomes a gauge for levels of "civilization" or humanity. Throughout history, responses to requests for asylum and hospitality have been central to the discourse on morality, and in formulating the character of society, allowing for the isolation of the barbaric from the rest. A State's reputation can be created or destroyed depending on its response to appeals for asylum, which becomes a tool for glorification by friends or vilification by enemies. The Plataeans, aware of this, use it in making their argument when supplicating the Athenians. ${ }^{49}$ They praise their reluctant host for being known as a friend to refugees, welcoming and open from the time of their ancestors. This, they stress, has brought Athenians glory, which they would risk losing by refusing the pleas of the Plataeans. Hence, the very existence of these Plataean refugees gives Athens an opportunity for glory, or conversely for its loss. In their own myths, the Athenians prided themselves for not giving in to external pressure to give up their asylum-seekers or deny them shelter - an attitude which seems to echo the spirit of today's non-refoulement clause in Article 33 of the UN 1951 Geneva Convention on Refugees. ${ }^{50}$ Such decisions, however, were not easy, nor necessarily popular. Children of Herakles, the tragedy of Euripides, is in part about the community tensions that result from having to make such decisions. Within this play, despite the threat of war, there is resistance to giving up the suppliants sheltering in the sanctuary of Zeus at Marathon. The ultimate decision to provide shelter, while celebrated in the play, was hardly unanimous. The king of Athens, Demophon, laments his decision: ${ }^{51}$

Now you will see crowded assemblies being held, with some maintaining that it was right to protect strangers who are suppliants, while others accuse me of folly. If I do as I am bidden, civil war will break out.

48 Just two of the many works that grapple with this theme are Francois Hartog, The Mirror of Herodotus: The Representation of the Other in the Writing of History, University of California Press, Berkeley, CA, 1988; and Edward Said, Orientalism, Pantheon Books, New York, 1978.

49 Isocrates 14, Plataicus, lines 1-2, 39, 53.

50 Convention relating to the Status of Refugees, 189 UNTS 150, 28 July 1951 (entered into force 22 April 1954).

51 Euripides, Children of Heracles, trans. David Kovacs, Loeb Classical Library, 1995. 
The sentiment of ambivalence expressed in Euripides' tragedy stems from a seemingly deep-rooted fear of the stranger who comes unexpectedly-a guest who has the potential of turning conqueror. Narratives of such encounters are not uncommon, where welcoming locals are overwhelmed by their guests, either leading to political takeover or the expulsion of the host community. The legend of the women from Locri who became city founders in Italy, set in the seventh century BCE, is one such example. Polybius' version of it is the most detailed and provides one particular reading of the events some 500 years after their time. ${ }^{52}$ He recounts how women from Greek Locri, having abandoned their husbands, took their slaves and set sail for South Italy, where they arrived in the land of the Sicels. This group of outsiders, who were at first welcomed, soon turned on their hosts. After expelling the Sicels, they proceeded to rename their town Locri Epizephyrii, but interestingly continued to practice some of the local rituals, which were still going at the time of Polybius. Debates about this narrative were already prevalent in the ancient world, and were of interest to such thinkers as Aristotle, Timaeus and Polybius. This strange tale transforms from being one of encounter, with undertones of refugeehood, into a foundation myth. The refugee story of Aeneas and that of Romulus' asylum ${ }^{53}$ are, equally, versions of foundation myths with similar undertones of displacement. Through them, Rome could be presented as an open city that was welcoming to refugees. At their most basic, however, these are narratives of colonization.

Athenians, unlike Romans, believed themselves to be autochthonous primordial inhabitants sprung from the land - yet their self-presentation was also one of being open to refugees and outsiders. ${ }^{54}$ This image was in part intended as a contrast to their Spartan enemies, who threw outsiders out - a practice depicted as inhuman in ancient writings, perhaps comparable to disregarding nonrefoulement directives. ${ }^{55}$ According to the Greek historian Thucydides, the insults between these two great poleis in the run-up to the Peloponnesian War (431-04 BCE) included the other's disregard for hiketeia-supplication. ${ }^{56}$ Such things mattered not only for a city's reputation on the global stage, but also, and perhaps more importantly, as a way of showing that the city was not transgressing the will of the gods, for whom guests and suppliants were sacred. Whether the two poleis were in fact that different from each other may be

52 Polybius 12.4d-12.12a. On the myth, see James M. Redfield, The Locrian Maidens: Love and Death in Greek Italy, Princeton University Press, Princeton, NJ, 2003, pp. 203-308; Christiane SourvinouInwood, "The Votum of $477 / 6$ B.C. and the Foundation Legend of Locri Epizephyrii", Classical Quarterly, Vol. 24, No. 2, 1974; Frank W. Walbank, "Polemic in Polybius", Journal of Roman Studies, Vol. 52, No. 1-2, 1962.

53 Livy 1.8.6.

54 For autochthony, see Nicholas Purcell, "Mobility and the Polis", in Oswyn Murray and Simon Price (eds), The Greek City from Homer to Alexander, Clarendon Press, Oxford, 1990; P. Horden and N. Purcell, above note 3, p. 384; John-Paul Wilson, "Ideologies of Greek Colonization", in Guy Bradley and John-Paul Wilson (eds), Greek and Roman Colonization: Origins, Ideologies and Interactions, Classical Press of Wales, Swansea, 2006 p. 32.

55 Thucydides 1.144.2, 1.67, 139.1, 2.39.1; Herodotus on Sparta being closed to strangers: 1.65.6-9; 1.69-79. See also U. Sinn, above note 22, p. 71; R. Garland, above note 26, pp. 95-98, 126.

56 Thucydides 1.126-128. 
questionable. Athens' exclusionary citizenship policy, in line with the myth of autochthony, makes the extent of its openness suspicious. Yet, such a position need not be contradictory. There is some evidence of a separation between living on the land and sharing in the political affairs of the community, which we witness emerging in the Classical period of the fifth century BCE, particularly in tragedy. ${ }^{57}$ The city could be a place of refuge and even a permanent home to foreigners, while it separated out those who were perceived as not having an equal investment in the polis. It is a distinction which is embodied in the status of the metic - the resident alien. ${ }^{58} \mathrm{~A}$ similar distinction is made some centuries later by the Roman statesman Cicero, in his De Officiis, but in relation to foreigners in general: ${ }^{59}$

$[\mathrm{N}]$ o cruelty can be expedient; for cruelty is most abhorrent to human nature, whose lead we ought to follow. They do wrong, those who would debar foreigners from our cities and would drive them out (as was done by Pennus in the time of our fathers, and recently by Papius.) Of course it is right not to permit the rights of citizenship to one who is not a citizen (on which point a law was secured by two of our wisest consuls, Crassus and Scaevola). Still, to debar foreigners from using the city is clearly inhuman.

This dilemma about the right of access to the land and to community membership has not subsided in the world of territorial States. The tension was there right at the advent of the nation-State, as expressed in Kant's articulation of the cosmopolitan right to hospitality. ${ }^{60}$ It delimited the civic space by regulating relations among members and strangers. For both Cicero and Kant, although operating in very different contexts, hospitality lay at the boundary of civic society and the international community, in the space between civil rights and human rights. For De Genova, deportation becomes the locus for theoretical elaboration of the "coconstituted problems of the state and its putative sovereignty, on the one hand, and that elementary precondition of human freedom, which is the freedom of movement". ${ }^{61}$ These examples demonstrate instances throughout history when the conceptualization and treatment of strangers, within the broad context of hospitality, allows not only for the measure of a community's humanity, but also for an articulation of the nature and intrinsic meaning of community at a given moment in time. Outsiders have the power to shape the character of States and help in their self-definition. The current, almost weekly political marches across the world, and local resistance in response to the increasingly harsh policies of

57 G. W. Bakewell, above note 24, pp. 58, 103-105, 121-125.

58 D. Kasimis, above note 17.

59 Cicero, De Officiis, trans. Walter Miller, Loeb Classical Library, 1928, 3.11.47. Translation by author, adapted from the translation by W. Miller; the brackets are my own.

60 See Immanuel Kant, Perpetual Peace, and Other Essays on Politics, History, and Morals, trans. Ted Humphrey, Hackett Publishing, Indianapolis, IN, 1983, and discussion in S. Benhabib, above note 15, pp. 27, 40 .

61 N. De Genova, above note 16, p. 39. 
Western countries towards those who seek asylum, are rapidly redefining the meaning of community, nationhood and citizenship. ${ }^{62}$

From the perspective of people who consider themselves to be citizens or nationals, displaced persons such as refugees become a particular form of outsider - the "other". This is an "otherness" not constituted through any claims to a specific ethnicity or place of origin, but resulting from the condition of displacement itself. The perceived disconnection from any community, or any recognizable political structures or institutions, is what causes discomfort for those who are State-based. There is a volatility to the actions of people who have been displaced which defies their positioning on a recognizable political spectrum, making any such group a potential threat to existing structures and the status quo. Such fear is most directly expressed in Polybius' account of the Mercenary War that threatened Carthage in the wake of its defeat by Rome in the mid-third century BCE. ${ }^{63}$ While the group he focuses on are neither asylumseekers nor refugees, the predicament of the mercenaries who gather at Sicca has many affinities with that of people who end up in a suspended state of existence in refugee camps. The basic story is that following the First Punic War, the mercenaries who had fought with the Carthaginians in Italy returned to Carthage to collect the fees for their services. However, Carthage could not afford to pay them, so it insisted that they wait in a camp at Sicca, some 200 kilometres west of Carthage. Tired of waiting for a Carthaginian response, the mercenaries, who were from diverse backgrounds, organized themselves in a loosely representational system of governance. Polybius associated them with the worst kind of populist movements and radical politicians, which he presents as the antithesis to the polis. ${ }^{64}$ The mercenaries had enough authority and organizational capacity to gain other States as allies and to pressure Carthage to honour its commitment. In Polybius' presentation of the group, there is no recognition that these mercenaries were also likely citizens of other States. What mattered to him was that in their mass, in their mixity and statelessness, they formed the extreme end of a spectrum, at the opposite end of which was the exemplary polis, embodying the ideal and only acceptable form of politics and community.

The same attitude may be detected in Isocrates' writings in the fourth century BCE, which show little sympathy for those who wander helpless and homeless on the grounds that they present a threat to civilized society. ${ }^{65}$ In positioning displaced people as stateless, their particular otherness is maintained. Reflecting on this in the context of the twenty-first-century crisis of mass displacement, Bradley argues that the persistent and un-nuanced conflation of

62 For example, the refusal of federal appeal courts in the United States, including that of Hawaii, to uphold the president's order of 6 March 2017 banning people from six Muslim-majority countries from entering the United States: see Dan Levine and Lawrence Hurley, "Another U.S. Appeals Court Refuses to Revive Trump Travel Ban", Reuters, 12 June 2017.

63 Polybius 1.66-1.67.

64 Craige B. Champion, Cultural Politics in Polybius's Histories, University of California Press, Berkeley, CA, and London, 2004, p. 207; E. Isayev, above note 3, Ch. 8.

65 Isocrates 19, Aegeneticus; R. Garland, above note 26, p. 24 
refugeehood and statelessness represents a potential disservice to the displaced. ${ }^{66}$ The danger is that it may perpetuate a mistaken impression of refugees as politically impotent victims, and unintentionally undermine their compelling claims against their States of origin. Building on Arendt's examination of statelessness, Gundogdu demonstrates the way in which the resulting condition of rightlessness is challenged by the political practices of people who are displaced. ${ }^{67}$

The potency of contingent agency is perceptible in the extent to which those who are displaced are deeply embedded in the discourse of community boundaries. Furthermore, merely through finding themselves in the position of being displaced, such people create a measure for society by providing the opportunity for acts of honour, heroism and charity.

\section{Willed}

The second form of agency is willed, anticipated, resolute and conscious. It refers to the power that people seeking refuge have in their appeals for protection, asylum or recognition. The paradox is that despite the necessity for active persuasion, they are often positioned as helpless victims. Such conflicts are explicitly addressed in ancient literature, confronting issues of obligation and the host's struggle over whether to give asylum, as in the Greek tragedies of Aeschylus and Euripides. Unlike contingent agency, which affects internal and inter-State relationships, willed agency concerns the relationship between the asylum-seeker and the host. It also includes the relationship of both to an ambivalent higher power, whether divine will, ancestral tradition, international law, or the directives of an organization such as the UN.

Appeals for refuge may be made on the basis of both negative and positive criteria, as outlined above. Key to their success is the process of petitioning, or what is referred to in the ancient world as supplication, which requires willed agency. There is a carefully measured and methodical process to the ritual of public supplication, often conducted from the protective site of a sanctuary. ${ }^{68}$ This brings it into the realm of politics, with god and altar acting as intermediaries in a transaction between suppliant and polis. The sanctuary is thus revealed as a site of contestation. ${ }^{69}$ On the surface, the supplication ritual may appear as a power game conducted between the seemingly powerless suppliant, the powerful polis and the most powerful god. ${ }^{70}$ However, if the suppliant was indeed so powerless, the transaction would not work. In ancient literature, at least, the possibility of punishment for not addressing suppliant appeals is taken seriously. In deciding whether to help the Danaids, the Argive king Pelasgos is wary of the heavy wrath of Zeus Hikesios, the protector of suppliants, stating that the fear of him is the

66 M. Bradley, above note 15, pp. 101-103, 107.

67 H. Arendt, above note 11, p. 267; A. Gundogdu, above note 11, especially Ch. 4.

68 R. Garland, above note 26, pp. 125-126; J. Gould, above note 27, p. 101; F. S. Naiden, above note 27.

69 J. J. Bagelman, above note 10, p. 85.

70 F. Zeitlin, above note 24, p. 211. 
greatest a mortal can have. ${ }^{71}$ It was not just the removal of suppliants from a sanctuary that was considered a sacrilege; ${ }^{72}$ divine retribution could result from the pollution of sanctuaries and altars, through a final extreme act of defiance by those seeking refuge. Aeschylus' Suppliant chorus plead with Pelasgos the Argive king: ${ }^{73}$

Think, and become wholeheartedly

our pious sponsor

do not betray the fugitive

who comes from afar, set in motion

by an impious expulsion

Standing against the looming statues of their divine protectors, they threaten that if their entreaties are ignored,

With all speed [we will] hang ourselves from these gods.

When voice has failed, the last resort is to use the one remaining vehicle of agency: one's being, the body, through the threat of its destruction by suicide. In its many forms, this is still the most potent act of willed agency by refugees and asylumseekers. Its power, however, and arguably that of other acts of supplication, is dependent on having witnesses present. Who are the witnesses to such acts today? Proximity to those seeking protection is increasingly lacking, as the buffer zone of intermediaries and the bureaucratic apparatus, with its expanding document-based procedures, all but removes accountability in a process of dehumanization. It reduces people as inherently complex beings to what Stevens, in her analysis of the "alien who is a citizen", casts in the image of "stick figures who possess just one thin and arbitrary set of characteristics of interest for the law: their own government-written documents and references to these in state registries". 74

Unsympathetic treatment of suppliants always has moralistic undertones in ancient literature, and its power may be seen in the many legends that arose over the centuries from the crimes against them. ${ }^{75}$ The madness of Kleomenes, king of Sparta, is attributed to divine retribution for putting to death thousands of Argive suppliants, who were taking refuge in a sacred grove. ${ }^{76}$ The earthquake and tidal wave that buried the ancient Achaean city of Helike in 373 BCE were perceived as a response by the gods to the city's crime against the suppliants sheltering in its sanctuary of Poseidon. ${ }^{77}$ Natural catastrophes that affected ancient Sparta,

71 Aeschylus, above note 23, lines 347, 472-479.

72 R. Garland, above note 26, pp. 122, 125-126; F. Zeitlin, above note 24, p. 206.

73 Aeschylus, above note 23, lines 418-423.

74 Jacqueline Stevens, "The Citizen Who Is an Alien”, in Benjamin Rawlance and Jacqueline Stevens (eds), Citizenship in Question: Evidentiary Birthright and Statelessness, Duke University Press, Durham, NC, and London, 2017, p. 219. This volume of collected papers as a whole addresses the way in which the document manifests society.

75 E. Belfiore, above note 39 , pp. 143-144; U. Sinn, above note 22, p. 71.

76 Herodotus 6.75.3.

77 Pausanias 7.25.1. Also, the Spartan earthquake was blamed on their ejection of the Helots from the Poseidon Sanctuary in 464 BCE: see Thucydides 1.128.1. 
Sybaris, Metapontum, Croton, Aegina and a number of other poleis are traced back to the mistreatment of suppliants. ${ }^{78}$ These stories may be symbolic of the power that such threats could potentially have, but they also show the numerous instances when such appeals were ignored and, despite the threats of divine retribution, were unsuccessful. The question is, to what extent is there any real power in being held to account, and does the pressure come from the outside or from within? The current policies on refugees and asylum-seekers, in such States as the United Kingdom, the United States and Australia, for example, suggest that there is little weight to any pressure from such higher powers as the UN. Nevertheless, it is evident that some power remains, paradoxically, in the great pains that States take to follow the letter of the law when it comes to human rights, in search of legal loopholes to reduce the number of refugees they would have to support. In the ancient world one of the avoidance tactics was to prevent asylum-seekers from reaching the safety of the sanctuary in the first place, for example by prohibiting foreigners' entry into the sacred precincts, where they would be under the protection of the gods. ${ }^{79}$ Today's creative approaches to avoiding responsibility owed to those who seek refuge have led some States to declare their airport arrival areas and other border entry points not part of their territory for purposes of asylum. ${ }^{80}$

\section{Compelled}

The final form of agency is that which is compelled. It emerges out of necessity during extended periods of displacement or waiting, whether at a sanctuary, camp or other liminal space - a condition that has been labelled a "state of exception". ${ }^{81}$ The workings of compelled agency are evident in the relationships and systems that form within displaced groups and which can result in creative politics. Such lengthy suspended states are rare in ancient historical contexts, as are similar spaces of extended liminality, such as refugee camps. The waiting period for those seeking protection appears to have been much shorter, generally a matter of days or even months, but rarely years. In part, this may have been due to the fact that responses to asylum requests were given comparatively quickly. A failed decision that did not result in death often led to the dispersal of the suppliant group to other sites, where the lucky ones may have been accepted into communities on an individual basis, while others continued their wandering. From what is known, any long-term residency at sanctuaries, for example, was exceptional, not least because these sites continued to be used for religious

81 For the state of exception, see G. Agamben, above note 2; J. Huysmans, above note 2; C. Schmitt, The Concept of the Political and Political Theology, above note 2. On theories of migrant detention and detainability, see N. De Genova and N. Peutz, above note 16; Nicholas De Genova, "Detention, Deportation, and Waiting: Toward a Theory of Migrant Detainability", Global Detention Project Working Paper No. 18, November 2016. 
celebrations and festivals such as the Olympic Games. ${ }^{82}$ During these events, suppliants mixed with festival-goers under the protection of the gods. Furthermore, while suppliants may have been common at these sites, ${ }^{83}$ the priests, who were their custodians, had limited capacity to sustain sizeable groups for any length of time. Displacement for any extended period may also be hard to recognize in the ancient world because after a certain point the people living under such conditions, if they are not killed or enslaved, are no longer portrayed as the displaced. Once they are in a position of engaging in politics, their status changes (even if not in the form of citizenship) and ancient authors write about them as founders, conquerors or colonizers. So the stories of asylum sought by Romulus and Aeneas, who come in as outsiders, transform into the founding myths of Rome. Their agency can no longer be defined as compelled once they are part of autonomous entities, and their condition stops being one of transience.

Although more rare, there are ancient contexts where traces of such agency may be recognized. Most simply, it emerges in the way that asylum-seekers organize themselves when making their appeals. The Danaids of Aeschylus' tragedy, for example, in the form of a chorus, resolve how to plead with the Argives - what supplicating position they will take and which arguments they will put forward. ${ }^{84}$ Beyond the realm of myth and drama, the predicament of the Carthaginian mercenaries in the camp at Sicca provides a more profound insight into the workings of compelled agency within historical groups in a state of transience. While, as noted earlier, this group was not made up of people in search of refuge, arguably aspects of their condition reflect those experienced by asylum-seekers while waiting for their claims to be addressed. What we witness of this experience, through the writings of Polybius, perhaps comes closest to the practices of collective decision-making and action that may have developed at other liminal sites of refuge such as sanctuaries, if on a smaller scale. As we have already seen, the historian Polybius, who recounts their exploits, has his own reasons for presenting mercenary deliberations and decision-making in a particular light: as dynamic populism, which he finds abhorrent. ${ }^{85}$ Still, whatever the nature of the organizational process of this group, what is of interest is what this new entity was able to achieve. These mercenaries of different backgrounds, speaking diverse languages, did not just wait passively; they challenged their suspended state. In activating their common ground, they gained enough power to wage war against Carthage and to draw in allies beyond the mercenary group, who joined in their campaign. At Sicca, as in Aeschylus' mythical Argive sanctuary, or Romulus' asylum of future Rome, it is not states of exception devoid of agency that are found, but dynamic meshworks and crucibles of a new exceptional politics.

82 R. Garland, above note 26, pp. 22, 125-126.

83 U. Sinn, above note 22; A. Chaniotis, above note 22, p. 69.

84 Aeschylus, above note 23, lines 191-199 and throughout.

85 Polybius 1.66-1.67. 


\section{Politics of exception}

Today's protracted states of suspension are extreme, not only because of refugee camps, but also because of the prevention of mobility itself. Although protected under Article 13 of the Universal Declaration of Human Rights, freedom of movement is to be understood not as a right, but as inseparable from being human. In De Genova's articulation, it is "a necessary premise for the free and purposeful exercise of creative and productive powers", the foundation for all properly social praxis. ${ }^{86}$ Despite the denial of autonomous movement, as its existence is an affront to State sovereignty, ${ }^{87}$ in such liminal spaces as the camp that elicit compelled agency, one can trace the emergence of systems which allow communities to function beyond mere survivalism, while still eluding normalization. This final example will serve to demonstrate the workings of compelled agency in the context of the twenty-first century. The conceptualization of exceptional politics has emerged from the experience of refugee camps in Palestine. It appears in such initiatives as the Collective Dictionary-a type of dynamic constitution - created through the Campus in Camps programme. ${ }^{88}$ In one of the volumes related to it, called The Suburb, it presents what may appear, at first, an absurd predicament. ${ }^{89}$ In 2012, a new neighbourhood on the edge of Dheisheh Refugee Camp was created, mainly, but not exclusively, by refugees who had moved out from the cramped conditions of Dheisheh itself - a camp established in 1949 for 3,000 inhabitants but now housing some 15,000 people. ${ }^{90}$ The capacity of this new suburb was equivalent to that of nearby villages and other surrounding municipalities, such as the city of Doha. It was therefore not surprising that the city council of the adjacent village of Irtas requested that the suburb should join it by coming under its jurisdiction. ${ }^{91}$ However, the community of Al-Shuhada refused these offers and instead made the seemingly impossible request to become part of the camp. This is technically inconceivable because of the protective and constraining UN cordon that outlines the camp territory.

In their investigation of this seemingly absurd situation of Dheisheh and the suburb, the authors of the volume sketch out the delicate and dynamic practices that showcase the camp as a site of innovative and influential, if exceptional, politics. They trace the emergence of systems which balance the need for allowing the functioning of community beyond mere survivalism and articulating the refugee voice without normalizing the existence of the camp. The residents of Al-Shuhada wanted their suburb to be part of the camp because it was there that they felt they could be most well represented, protected and heard

86 N. De Genova, above note 16, p. 39.

87 Ibid., p. 39.

88 Campus in Camps, available at: www.campusincamps.ps (all internet references were accessed in March 2017).

89 Qussay Abu Aker and Ahmad Al Lahham, The Suburb: Transgressing Boundaries, Campus in Camps, Dheisheh Refugee Camp, 2013, available at: www.campusincamps.ps/projects/05-the-suburb/.

90 Data as of 14 June 2017: see UNRWA, "Dheisheh Camp", available at: www.unrwa.org/where-we-work/ west-bank/dheisheh-camp.

91 Q. Abu Aker and A. Al Lahham, above note 89, p. 24. 
beyond the camp, within and outside Palestine. This dynamism challenges Arendt's predominant characterization of refugees as having been stripped of their political agency, and Agamben's conception of the camp as the depoliticized state of exception. Instead, as the architect and educator Alessandro Petti has observed, "the prolonged exceptional temporality of this site has paradoxically created the condition for its transformation: from a pure humanitarian space to an active political space". ${ }^{92}$ It also challenges the conventional model of the city as the primary site of politics. As the authors state in their reflection on writing The Suburb: $:^{93}$

The study of the suburb is an occasion to highlight some of these strengths and achievements so that we can use these accomplishments in the narration of our story. In proving that refugees have the right to return we can show everything they have achieved in exile, rather than only showing ourselves as weak, poor, and victims.

\section{In conclusion}

Ancient Sicca and modern Dheisheh are over 2,000 years apart, and the circumstances of their creation and existence are hardly similar. What they have in common is their seemingly transient and suspended state of being, where a compelled agency leads to an exceptional politics. Despite not being recognized as a political community, they have made their actions and their speech relevant the defining practices of such a community. ${ }^{94}$ Whether these communities are pioneering or threatening, they defy the conventional model of the city as the primary site of politics and demand engagement from nation-State actors. They require consideration of how extra-State actors can engage directly with global institutions and legal frameworks. The alleged transience of such enterprises as refugee camps is increasingly gaining permanence and fixity: almost seventy years old, some camps in Palestine are fast becoming heritage sites, and these are only the most well-known. Yet the "right to have rights", as Arendt defined it, despite advances in the institutionalization of human rights norms, still remains within the confines of a State-centric international law. ${ }^{95}$ How long will people be expected to continue living in such transient states in these and other sites, which most people on the street have never heard of, such as the enormous Dadaab Refugee Complex, which by its size would be equivalent to the second-largest "city" in Kenya?96 This situation is no longer transient or exceptional - it is unsustainable doublethink. Instead, by acknowledging the agency of people who

92 Ibid., p. 9.

93 Ibid., p. 69.

94 On rightlessness, see $\mathrm{H}$. Arendt, above note 11.

95 Ibid. Reading Arendt against the grain to address practices that increasingly challenge such constraints, see A. Gundogdu, above note 11 .

96 Ben Rawlence, City of Thorns: Nine Lives in the World's Largest Refugee Camp, Portobello Books, London, 2016. 
are displaced, both current and historical, it becomes possible to explore its diverse forms and potency. In so doing, an opening can be created for modes of engagement with the innovative, socio-political models that arise from exceptional conditions, ones that are neither idealized nor reactionary. It forces a rethinking of the model of political agency, encouraging a reconceptualization of the political in terms that move beyond citizenship. ${ }^{97}$ Drawing on the deep, intergenerational expertise and creativity of such lived experience, held by a population in the tens of millions, has the potential to overcome the seemingly intransient, State-based understanding of rights and power. 